\title{
Hubungan Antara Dukungan Keluarga dan Motivasi Dengan Kualitas Hidup Pada Pasien yang Menjalani Terapi Hemodialisa di Rsi Sultan Agung Semarang
}

\author{
Deni Rizky Sulymbona1a, Retno Setyawati ${ }^{1 b}$, Furaida Khasanah ${ }^{2 c^{*}}$ \\ ${ }^{1}$ Fakultas Ilmu Keperawatan Universitas Islam Sultan Agung Semarang, Indonesia \\ 2 Poltekkes Kemenkes Yogyakarta, Indonesia \\ a denyrizky@gmail.com \\ b retno_fik@gmail.com \\ c furaida.khasanah@poltekkesjogja.ac.id \\ * coresponding author
}

\begin{tabular}{ll}
\hline \multicolumn{2}{l}{ Article History } \\
\hline Submitted & $:$ 20 Jan 2020 \\
Accepted & $: 20$ April 2020 \\
Revision & $: 20$ Feb 2020 \\
Published & $: 30$ April 2020
\end{tabular}

Key word:

Family Support

Motivations

Life Quality

\begin{abstract}
Kualitas hidup pasien penyakit ginjal kronis yang menjalani terapi hemodialisis masih merupakan masalah yang menarik perhatian para profesional kesehatan, pasien akan merasa berharga jika mendapatkan dukungan dari keluarga dan memiliki motivasi untuk menjalani terapi hemodialisa. Tujuan penelitian untuk mengetahui dukungan keluarga dan motivasi dengan kualitas hidup pada pasien yang menjalani terapi hemodialisa di RSI Sultan Agung Semarang. Penelitian ini merupakan studi analitik observasional, menggunakan teknik total sampling dengan jumlah responden 87. Pengumpulan data menggunakan kuesioner. Teknik analisa data menggunakan uji chi square. Uji chi square untuk dukungan keluarga dengan kualitas hidup didapatkan hasil $p$ value 0,005 , sedangkan untuk motivasi dengan kualitas hidup pasien hemodialisa nilai $\mathrm{p}$ value 0,0001 . Dukungan keluarga dan motivasi berhubungan dengan kualitas hidup pada pasien yang menjalani hemodialisa. Perawat sangat berperan penting untuk memberi support dan motivasi terhadap pasien dan keluarga.
\end{abstract}

Life quality of chronic kidney disease patients who undergoing hemodialisa theraphy is still being an attractive problem for health professionals, patient will feel worth if they get support from their family and have motivation to undergo hemodialysis therapy. This research aims to acknowledge family support and motivation with life quality in patients undergoing hemodialysis therapy in Islamic Sultan Agung Hospital Semarang. This research is analytic observational study, using total sampling technique with 87 numbers of repondent. Data collecting using questionry. Data Analysis technique using chi square test. Chi quare test for family support and life quality discovers result $p$ value 0,005 , meanwhile for motivation and life quality hemodialysis patients $p$ value 0,0001 . Family support and motivation is correlated wit life quality on patients undergoing hemodialysis. Nurse have the big role to give support and motivation toward patients and family. 


\section{Pendahuluan}

Hemodialisis (HD) merupakan prosedur medis untuk pasien yang telah kehilangan fungsi ginjal baik sementara maupun permanen karena Penyakit Ginjal Kronik (PGK). ${ }^{1}$ Hemodialisis merupakan suatu teknologi tinggi sebagai terapi pengganti fungsi ginjal untuk mengeluarkan sisa-sisa metabolisme atau racun tertentu dari peredaran darah manusia seperti air, natrium, kalium, hydrogen, urea, kreatinin, asam urat, dan zat-zat lain melalui membran semi permeable sebagai pemisah darah dan cairan dialisat pada ginjal buatan di mana terjadi proses difusi, osmosis dan ultrafiltrasi. Dialisis digunakan untuk pengobatan jangka panjang untuk PGK atau sebagai pengobatan sementara sebelum penderita menjalani pencangkokan ginjal. ${ }^{2}$

Berdasarkan data dari WHO secara global pada tahun 2013 lebih dari 500 juta orang menderita PGK, dan 1,5 juta orang yang melakukan hemodialisa. Penderita PGK semakin meningkat jumlahnya, di Amerika pada tahun 2009 diperkirakan terdapat 116395 orang penderita PGK yang baru. Lebih dari 380000 penderita PGK menjalani hemodialisis reguler.

Hemodialisis di Indonesia sudah ada sejak tahun 1970 dan sampai sekarang, pada tahun 2011 di Indonesia terdapat 15353 pasien yang baru menjalani HD dan pada tahun 2012 terjadi peningkatan pasien yang menjalani HD sebanyak 4268 orang sehingga secara keseluruhan terdapat 19621 pasien yang baru menjalani HD, sehingga hal ini menjadi suatu perhatian khusus, karena PGK bisa menimbulkan beberapa komplikasi seperti kelebihan cairan, hiperglikemia, hipertensi dan disfungsi seksual yang berakibat pada penurunan kualitas hidup pasien baik dari segi fisik, mental, sosial dan lingkungan.

Kualitas hidup merupakan pandangan seseorang terhadap posisi individu dalam konteks budaya, nilai dimana mereka hidup dan dalam hubungannya dengan tujuan hidup dan harapan. Kualitas hidup pasien PGK yang melakukan terapi hemodialisis masih merupakan masalah yang menarik perhatian para profesional kesehatan. Pasien bisa bertahan hidup dengan menjalani proses hemodialisis, namun masih menyisahkan beberapa persoalan penting sebagai dampak dari terapi hemodialisis. Mencapai kualitas hidup perlu perubahan fundamental atas cara pandang pasien terhadap penyakit ginjal kronis itu sendiri. Pasien yang memiliki pendidikan lebih tinggi akan mempunyai pengetahuan yang lebih luas yang memungkinkan mampu mengontrol dirinya dalam mengatasi masalah yang dihadapi dan mempunyai rasa percaya diri yang tinggi. ${ }^{3}$

Pasien PGK yang menjalani hemodialisa akan merasa dirinya lebih berharga saat mendapat dukungan dari keluarga. Dukungan keluarga merupakan sikap, tindakan dan penerimaan keluarga terhadap penderita yang sakit yang membutuhkan bantuan dan pertolongan baik dalam peningkatan harga diri, pemberian keamanan, hingga pemecahan suatu masalah yang dihadapi dalam rangka menjalani fungsi keluarga dimana dukungan keluarga berpengaruh terhadap kesehatan mental penderita serta sebagai strategi preventif 
untuk mengurangi stress dimana pandangan hidup menjadi luas dan tidak mudah stress. Dukungan keluarga terbagi atas dukungan penilaian, dukungan instrumental, dukungan informasional, dan dukungan emosional. ${ }^{4,5}$

Kepatuhan pada PGK dalam melakukan terapi hemodialisis merupakan hal yang sangat penting untuk diperhatikan, apabila pasien tidak patuh dalam menjalani terapi hemodialisis akan terjadi penumpukan zat-zat berbahaya dalam tubuh. Kepatuhan terapi hemodialisis juga berdampak pada berbagai aspek perawatan pasien, termasuk konsistensi kunjungan, serta pembatasan makanan dan cairan. Kepatuhan dapat dipengaruhi oleh berbagai faktor, diantaranya keyakinan, sikap dan motivasi pasien, pengetahuan, persepsi, harapan pasien, dukungan sosial keluarga, dan dukungan petugas kesehatan. Motivasi merupakan salah satu faktor yang dapat meningkatkan kepatuhan pasien. Motivasi merupakan sesuatu yang mendorong atau pendorong seseorang bertingkah untuk mencapai tujuan tertentu.

Hasil studi pendahuluan yang dilakukan di RISA Semarang jumlah pasien yang melakukan hemodialisa dari bulan Januari sampai bulan Juli 2016 sebanyak 87 pasien, diantaranya laki-laki sebanyak 64 orang dan perempuan sebanyak 23 orang. Hasil observasi 6 dari 8 pasien hemodialisa terlihat ditemani oleh anggota keluarganya, 4 pasien mengatakan ada yang masih bekerja dan ada 4 pasien yang sudah tidak bekerja lagi serta meninggalkan segala aktivitas yang berhubungan dengan lingkungan sekitarnya.

\section{Metode Penelitian}

Desain penelitian ini menggunakan dengan desain cross-sectional. Pada desain crossectional, peneliti hanya melakukan pengukuran variabel tidak harus dilakukan pada satu waktu bersamaan (Nursalam, 2011). Populasi dalam penelitian sebanyak 87 orang.

Teknik pengambilan sampel dilakukan dengan teknik Total Sampling yaitu 87 responden. Penelitian ini dilaksanakan bulan Januari 2017. Data diperoleh dengan menggunakan kuesioner.

\section{Hasil}

\section{A. Analiss Univariat}

\section{Umur}

Tabel 1. Disttribusi Frekuensi Karakteristik Responden Berdasarkan Umur di RSI Sultan Agung Semarang

\begin{tabular}{lcc}
\hline Umur & Frekuensi & Persentase (\%) \\
\hline Remaja (12-25) & 2 & $2,3 \%$ \\
Dewasa (26-45) & 41 & $47,1 \%$ \\
Lansia (46-65) & 37 & $42,5 \%$ \\
Manula (>65) & 7 & $8,0 \%$ \\
\hline Jumlah & 87 & 100 \\
\hline
\end{tabular}

Deni Rizky Sulymbona et.al (Hubungan Antara Dukungan Keluarga...) 


\section{Jenis Kelamin}

Tabel 2. Distribusi Frekuensi Karakteristik Responden Berdasarkan Jenis Kelamin di RSI Sultan Agung Semarang

\begin{tabular}{ccc}
\hline Jenis Kelamin & Frekuensi & Persentase (\%) \\
\hline Laki - laki & 64 & $73.6 \%$ \\
Perempuan & 23 & $26.4 \%$ \\
\hline Jumlah & 87 & 100 \\
\hline
\end{tabular}

\section{Pendidikan}

Tabel 3. Distribusi Frekuensi Karakteristik Responden Berdasarkan Pendidikan di RSI Sultan Agung Semarang

\begin{tabular}{ccc}
\hline Pendidikan & Frekuensi & Persentase $(\%)$ \\
\hline SD & 8 & $9.2 \%$ \\
SMP & 18 & $20.7 \%$ \\
SMA & 51 & $58.6 \%$ \\
PT & 10 & $11.5 \%$ \\
\hline Jumlah & 87 & 100 \\
\hline
\end{tabular}

\section{Pekerjaan}

Tabel 4. Distribusi Frekuensi Karakteristik Responden Berdasarkan Pekerjaan di RSI Sultan Agung Semarang

\begin{tabular}{ccc}
\hline Pekerjaan & Frekuensi & Persentase (\%) \\
\hline Tidak bekerja & 13 & $14.9 \%$ \\
Swasta & 42 & $48.3 \%$ \\
Wiraswasta & 25 & $28.7 \%$ \\
PNS & 7 & $8.0 \%$ \\
\hline Jumlah & 87 & 100 \\
\hline
\end{tabular}

\section{Lama HD}

Tabel 5. Distribusi Frekuensi Karakteristik Responden Berdasarkan lama HD di RSI Sultan Agung Semarang

\begin{tabular}{ccc}
\hline Lama HD & Frekuensi & Persentase $(\%)$ \\
\hline$<2$ tahun & 50 & $57.5 \%$ \\
$>2$ tahun & 37 & $42.5 \%$ \\
\hline Jumlah & 87 & 100 \\
\hline
\end{tabular}

\section{B. Analisa Bivariat}

1. Hubungan antara dukungan keluarga dengan kualitas hidu

Tabel 6. Analisa bivariat Hubungan dukungan keluarga dengan kualitas hidup di RSI Sultan Agung Semarang 


\begin{tabular}{|c|c|c|c|c|}
\hline \multirow[t]{2}{*}{ Dukungan keluarga } & \multicolumn{2}{|c|}{ Kualitas Hidup } & \multirow[t]{2}{*}{ Total } & \multirow[t]{2}{*}{ P value } \\
\hline & Baik & Buruk & & \\
\hline Baik & $33(76.7 \%)$ & $10(23.3 \%)$ & $43(100 \%)$ & 0.005 \\
\hline Sedang & $14(46.7 \%)$ & $16(53.3 \%)$ & $30(100 \%)$ & \\
\hline Buruk & $5(35.7 \%)$ & $9(64.3 \%)$ & $14(100 \%)$ & \\
\hline Total & $52(59.8 \%)$ & $35 \quad 40.2 \%)$ & $\begin{array}{cc}87 & (10 \\
& 0 \% \\
& \end{array}$ & \\
\hline
\end{tabular}

\section{Hubungan antara motivasi dengan kualitas hidup}

Tabel 7. Analisa bivariat Hubungan motivasi dengan kualitas hidup di RSI Sultan Agung Semarang

\begin{tabular}{lllll}
\hline Motivasi & \multicolumn{2}{c}{ Kualitas hidup } & Total & P value \\
\cline { 2 - 4 } & Baik & Buruk & & \\
\hline Tinggi Rendah & $43(72.9 \%)$ & $16(27.1 \%)$ & $59(100 \%)$ & 0.0001 \\
& $9(32.1 \%)$ & $19(67.9 \%)$ & $28(100 \%)$ & \\
\hline Total & $52(59.8 \%)$ & $35(40.2 \%)$ & $87(100 \%)$ & \\
\hline
\end{tabular}

\section{Pembahasan}

Dalam penelitian ini responden dengan kategori dewasa sebanyak 41 responden $(47,1 \%)$, lansia sebanyak 37 responden (42,5\%), manula sebanyak 7 responden $(8,0 \%)$ dan remaja sebanyak 2 responden (2,3\%). Dari penelitian ini pasien PGK yang melakukan hemodialisa sebagian besar adalah responden dengan kategori umur dewasa. Hal ini dikarenakan pola dan gaya hidup yang sering mengkonsumsi kopi dan juga bisa disebabkan karena mulai menurunnya fungsi organ tubuh manusia. Perubahan ini mencapai $50 \%$ dari fungsi ginjal secara normal. Seiring dengan bertambahnya usia seseorang menjadi rentan terhadap penyakit sistemik.

Pada penelitian ini didapatkan jumlah responden berjenis kelamin laki-laki sebanyak 64 responden (73,6 \%) dan responden berjenis perempuan sebanyak 23 responden $(26,1 \%)$.

Penelitian ini juga menemukan data latar belakang Pendidikan terbanyak responden dalam menjalani hemodialisa adalah responden berpendidikan SMA 51 responden $(58,6 \%)$, SMP 18 responden (20,7\%), PT 10 responden (11,5\%) dan SD 8 responden (9,2 \%). Azwar (2015) mengatakan bahwa semakin tinggi tingkat pendidikan seseorang maka dia akan cenderung positif karena pendidikan yang diperoleh dapat meletakkan dasar-dasar pengertian (pemahaman) dan perilaku dalam diri seseorang. ${ }^{6}$

Pekerjaan terbanyak dalam penelitian ini adalah pasien PGK dengan pekerjaan swasta 42 (48.3\%). Penelitian Asri (2006) mengatakan 2/3 pasien yang menjalani terapi hemodialisa tidak pernah kembali pada aktivitas atau pekerjaan seperti biasanya sehingga banyak pasien kehilangan pekerjaannya. ${ }^{7}$ Pekerjaan merupakan suatu kegiatan atau aktivitas seseorang yang bekerja pada orang lain atau instansi, kantor, perusahaan untuk memperoleh penghasilan yaitu gaji baik berupa uang maupun barang demi memenuhi kebutuhan hidup sehari-hari. Penghasilan yang rendah akan berhubungan dengan pemanfaatan pelayanan keehatan maupun pencegahan. Seseorang kurang memanfaatkan pelayanan kesehatan yang 
ada mungkin karena tidak cukup untuk membeli obat atau membayar transportasi (Notoatmodjo, 2010). ${ }^{8}$

Penelitian ini juga mendapatkan hasil lama responden dalam menjalani hemodialisa yaitu $<2$ tahun sebanyak 50 responden $(57,5 \%)$ dan $>2$ tahun sebanyak 37 responden $(42,5 \%)$. Penelitian yang dilakukan oleh Dewi, dkk(2015) mendapatkan adanya hubungan antara lama menjalani hemodialisa dengan kualitas hidup. Hal tersebut diatas juga dikuatkan oleh penelitian yang dilakukan oleh Nurchayati (2011) didapatkan adanya hubungan antara lama waktu menjalani HD dengan kualitas hidup dengan $p$-value $=0,035$ dan $\mathrm{OR}=2.637$, yang artinya responden yang belum lama menjalani HD beresiko 2,6 kali hidupya kurang berkualitas dibandingkan yang sudah lama menjalani HD. ${ }^{3}$

Pada penelitian ini didapatkan hasil adanya hubungan antara dukungan keluarga dengan kualitas hidup pasien penyakit ginjal kronik dalam menjalani hemodialisa di RSI Sultan Agung Semarang dan p-value 0.005 atau lebih kecil p-value 0.05. Penelitian Handayani (2012) didapatkan dukungan keluarga yang baik dengan kualitas hidup yang baik, 5 responden mendapatkan dukungan sedang dengan kualitas hidup baik, 6 responden mendapatkan dukungan keluarga sedang dengan kualitas hidup buruk dan 9 responden mendapatkan dukungan keluarga kurang dengan kualitas hidup buruk ${ }^{9}$. Penelitian dari Desita (2010) terdapat hubungan antara dukungan keluarga dengan kualitas hidup pasien ginjal kronik yang menjalani terapi hemodialisa di RSUP Haji Adam Malik Medan. ${ }^{10}$

Menurut Friedman (2010), terdiri atas dukungan penilaian, dukungan instrumental, dukungan informasional, dan dukungan emosional. Sedangkan dukungan keluarga mempengaruhi kualitas hidup seseorang dimana dukungan keluarga yang tinggi dapat akan lebih berhasil mengatasi masalahnya dibanding yang tidak mendapat dukungan keluarga. ${ }^{5}$

Dukungan keluarga termasuk salah satu faktor yang berhubungan erat terhadap tingkat kualitas hidup pasien ginjal kronik yang menjalani hemodialisa. ${ }^{11}$ Menurut Priyambodo (2007) kualitas hidup merupakan persepsi individu terhadap kehidupannya di masyarakat dalam konteks budaya dan sistem nilai yang berkaitan dengan tujuan, harapan, standar dan perhatian. ${ }^{12}$

Pada penelitian ini didapatkan hasil motivasi pasien hemodialisa sebagian besar tinggi sebesar $67,8 \%$ dan memiliki kualitas hidup yang baik sebesar $72,9 \%$ dan kualitas hidup yang buruk sebesar $27,1 \%$ dan hasil uji chi square didapatkan hasil $p$ value 0,0001 yang berarti ada hubungan yang signifikan antara motivasi dengan kualitas hidup pasien hemodialisa di RSI Sultan Agung Semarang

Motivasi sangat berpengaruh terhadap kualitas hidup pasien hemodialisa, baik motivasi dari dalam diri sendiri maupun motivasi dari luar, seperti adanya motivasi untuk menjaga kesehatan yang dilakukan dengan menghindari konsumsi air berlebih dan rutin melakukan hemodialisa sesuai jadwal. Hal ini merupakan bentuk motivasi dari dalam diri utnuk dapat menjaga kualitas hidup yang lebih baik, yang mempunyai pengaruh serta peranan yang sangat penting dalam menjaga kualitas yang baik. Apabila seseorang mempunyai keinginan dan juga harapan untuk meningkatkan kesehatan, maka secara tidak langsung kepuasan juga akan meningkat sehingga membuat seseorang menjadi tentram dan keempat dimensi dari kualita hidupun teratasi. Hasil penelitian ini sejalan dengan penelitian yang dilakukan oleh Atik (2014) yang meneliti tentang hubungan motivasi dengan kualitas hidup pasien gagal jantung dengan $p$ value $0,009 .{ }^{13}$ 


\section{Kesimpulan}

Hasil penelitian tentang hubungan dukungan keluarga dengan kualitas hidup pada pasien yang menjalani hemodialisa, didapatkan hasil dengan $p$-value 0.005 atau lebih kecil dari 0.05 dan hubungan motivasi dengan kualitas hidup pada pasien yang menjalani hemodialisa didapatkan hasil dengan p-value 0.0001 atau lebih kecil dari 0.05 .

\section{Daftar Pustaka}

1. Control CFD. National Chronic Kidney Disease Fact Sheet 2014.Division of Diabetes Translation National Center for Chronic Disease Prevention and Health Promotion.

2. Foote EF, Manley HJ. Hemodialysis and Peritoneal Dialysis. T J, ed.

3. Nurchayati S. Analisis Faktor-Faktor Yang Berhubungan Dengan Kualitas Hidup Pasien Penyakit Ginjal Kronik Yang Menjalani Hemodialisis Di Rumah Sakit Islam Fatimah Cilacap Dan Rumah Sakit Umum Daerah Banyumas. Depok: UI

4. Bosworth H. Friends \& Family Support Improve Heart Health.

5. Friedman LM. Buku Ajar Keperawatan Keluarga: Riset, Teori, Praktik. 5 th. Jakarta: EGC

6. Azwar S. Skala Psikologi. 2nd ed. Yogyakarta: Pustaka Belajar

7. P. A, Marthan MSW, Purwanta. Hubungan Dukungan Sosial dengan Tingkat Depresi Pasien yang Menjalani Terapi Hemodialisis.J1K. 01:02 2006 82-86.

8. Notoadmodjo S. Pendidikan dan Perilaku Kesehatan.

9. Handayani D, Wahyuni. Hubungan Dukungan Keluarga Dengan Kepatuhan Lansia Dalam Mengikuti Posyandu Lansia Di Posyandu Lansia Jetis Desa Krajan Kecamatan Weru Kabupaten Sukoharjo. J STIKES. 9:49-50.

10. Desiita. Pengaruh Dukungan Keluarga terhadap Peningkatan Kualitas. Hidup Pasien Gagal Ginjal Kronik yang Menjalani Hemodialisa di RSUP.

11. Anggraini S. Sistem Keamanan Data Dengan RSA Dan Modified LSB.Skripsi.Medan, Indonesia. Universitas Sumatra Utara

12. Priyambodo B. Manajemen Farmasi Industri. Yogyakarta: Global Pustaka Utama

13. Atik TW. Pengaruh Client Importance dan pergantian Auditor terhadap Kualitas Audit. 